Florida International University FIU Digital Commons

$11-10-2011$

\title{
Treefrogs in Forested Swamps at the La Selva Biological Station: Assemblage Variation through Space and Time
}

Vivian C. Maccachero

Florida International University, vmacc001@fiu.edu

DOI: $10.25148 /$ etd.FI11120507

Follow this and additional works at: https://digitalcommons.fiu.edu/etd

\section{Recommended Citation}

Maccachero, Vivian C., "Treefrogs in Forested Swamps at the La Selva Biological Station: Assemblage Variation through Space and Time" (2011). FIU Electronic Theses and Dissertations. 487.

https://digitalcommons.fiu.edu/etd/487 


\section{FLORIDA INTERNATIONAL UNIVERSITY}

Miami, Florida

TREEFROGS IN FORESTED SWAMPS

AT THE LA SELVA BIOLOGICAL STATION:

\section{ASSEMBLAGE VARIATION THROUGH SPACE AND TIME}

A thesis submitted in partial fulfillment of the

requirements for the degree of

MASTER OF SCIENCE

in

BIOLOGY

by

Vivian Cordeiro Maccachero

2011 
To: Dean Kenneth G. Furton

College of Arts and Sciences

This thesis, written by Vivian Cordeiro Maccachero, and entitled Treefrogs in Forested Swamps at the La Selva Biological Station: Assemblage Variation through Space and Time, having been approved in respect to style and intellectual content, is referred to you for judgment.

We have read this thesis and recommend that it be approved.

$\begin{array}{r}\hline \text { Joel T. Heinen } \\ \hline \text { Craig Guyer } \\ \hline \text { Maureen A. Donnelly, Major Professor }\end{array}$

Date of Defense: November $10^{\text {th }}, 2011$

The thesis of Vivian Cordeiro Maccachero is approved.

$\begin{array}{r}\begin{array}{r}\text { Dean Kenneth G. Furton } \\ \text { College of Arts and Sciences }\end{array} \\ \hline \begin{array}{r}\text { Dean Lakshmi N. Reddi } \\ \text { University Graduate School }\end{array}\end{array}$

Florida International University, 2011 


\section{DEDICATION}

For Enrico. 


\section{ACKNOWLEDGMENTS}

I want to thank Dr. Flona Redway of the MARC U*STAR program at Barry University and everyone involved with the Organization for Tropical Studies (OTS)Duke University 2005 REU program at La Selva for helping to jump-start this project and my graduate school career. I would also like to thank my labmates of the early and late years, J. Watling, A. Catenazzi, R. von May, R. Hegna, S. Murasaki, S. Whitfield, J. Nowakowski, K. Reider, L. Eluvathingal, and L. Linhoff for their continued support and friendship. A special thank you is owed to Ralph Saporito for his invaluable mentorship during the pre-graduate and early years, and to Monica Isola for holding my hand through this and so many other life experiences.

I also want to express my sincere gratitude to the following: OTS and the Tinker Foundation for providing financial support; Federico Bolaños and Jay Savage, who kindly shared their data with me thereby making this work possible; my committee members, Craig Guyer and Joel Heinen, who provided advice, support and helpful comments; Vincent Farallo and Padrick Anderson, for being the best (and funniest) field mates I could ever hope for. Finally, I would like to thank my major professor, Dr. Mo Donnelly, for always believing in me even (and especially) when I didn't believe in myself. Thank you for showing me the way.

My deepest gratitude is owed to my brother Victor and to my parents Vitorio and Miriam, the strongest people I know. Everything I do has always been and will always be for you. 


\author{
ABSTRACT OF THE THESIS \\ TREEFROGS IN FORESTED SWAMPS \\ AT THE LA SELVA BIOLOGICAL STATION: \\ ASSEMBLAGE VARIATION THROUGH SPACE AND TIME \\ by
}

Vivian Cordeiro Maccachero

Florida International University, 2011

Miami, Florida

Professor Maureen A. Donnelly, Major Professor

Swamp-breeding treefrogs form conspicuous components of many tropical forest sites, yet remain largely understudied. The La Selva Biological Station, a rainforest reserve in Costa Rica, harbors a rich swamp-breeding treefrog fauna that has been studied in only one of the many swamps found at the site. To understand if the species composition of treefrogs at La Selva varies over space or time, frogs were censused in 1982-83, 1994-95, 2005 and 2011 at two ponds located in the reserve. Data on treefrog habitat utilization were also collected. Species composition varied spatially only in 2011. Temporal variation was observed at both ponds for all groups tested. Habitat use varied among species and between swamps. The pattern of variation suggests that temporally dynamic systems such as temporary Neotropical forest swamps will converge and diverge in species composition over time. 


\section{TABLE OF CONTENTS}

CHAPTER

PAGE

I. INTRODUCTION

II. METHODS

III. RESULTS

11

IV. DISCUSSION

16

LITERATURE CITED

22 


\section{LIST OF TABLES}

TABLE

PAGE

1. Sampling scheme. 26

2. Date and study day number for the four sample periods. 27

3. Abundance of hylid frogs observed at the Research and Cantarana Swamps. 30

4. Species contributions to total average dissimilarity between swamps in 2011.

5. Species contributions to total average dissimilarity between study periods at the Research Swamp.

6. Pairwise tests for spatial and temporal comparisons of hylid species composition at the swamps in 2005 and 2011.

7. Substrate use by hylids at the Cantarana Swamp.

8. Substrate use by hylids at the Research Swamp. 


\section{LIST OF FIGURES}

FIGURE

PAGE

1. Swamps and trail systems at La Selva Biological Station.

2. Non-metric multidimensional scaling plots of spatial variation in species composition in 1994-95, 2005, and 2011.

3. Non-metric multidimensional scaling plots of temporal variation in species composition at the Research Swamp.

4. Non-metric multidimensional scaling plot of spatial and temporal variation in species composition at the swamps in 2005 and 2011.

5. Mean monthly rainfall at La Selva during 1963-2009 and total monthly rainfall in 1982 and 1994.

6. Mean monthly rainfall at La Selva during 1963-2009 and total monthly rainfall in 2005 and 2011.

7. Change in hylid frog abundance with rainfall. 


\section{INTRODUCTION}

The La Selva Biological Station has been the site of numerous herpetological studies. Swamp-breeding anurans form conspicuous components of many tropical forest sites, yet these anurans have been studied in only one of the many swamps found at $\mathrm{La}$ Selva. Donnelly and Guyer (1994) studied the patterns of reproduction and habitat use of Neotropical hylid frogs (treefrogs) in the "Research Swamp," located within an area of primary forest, during a fifteen-month period in 1982-83 (see Donnelly and Guyer 1994; Guyer and Donnelly 2005). Eleven members of the family Hylidae (treefrogs) were encountered during their study, but data for only eight hylid species (Agalychnis callidryas, A. saltator, Dendropsophus (=Hyla) ebraccatus, D. (=Hyla) phlebodes, Tlalocohyla (=Hyla) loquax, Scinax boulengeri, S. elaeochrous, and Smilisca baudinii) were included in their analysis. It is generally assumed by researchers working at $\mathrm{La}$ Selva that these species are common inhabitants of other swamps throughout the station. Although Donnelly and Guyer (1994) and Guyer and Donnelly (2005a) provided an overview of phenological patterns and calling phenology for swamp-breeding hylid frogs at the Research Swamp, it is not known if the patterns they described are characteristic of other swamp-breeding hylid frog assemblages across La Selva.

Since the Donnelly and Guyer (1994) study in the early 1980's, a boardwalk was installed in the "Cantarana Swamp," a swamp of equivalent size to the Research Swamp, located within the Ecological Reserve at La Selva. Data on the species richness and composition of the amphibians inhabiting the Research and Cantarana swamps were collected during an eighteen-month period in 1994-95 by Federico Bolaños and others as part of a study on amphibian declines in Costa Rica (unpublished data). I collected 
additional data on amphibian species richness and composition at the two swamps in June-July of 2005 and again in June-July 2011. Using the data collected by Donnelly and Guyer (1994), Bolaños and others, and myself, I examined hylid frog species composition to determine if it varied over time and space at two of the swamps at $\mathrm{La}$ Selva.

The use of amphibians as indicator taxa of ecosystem health and ecosystem disruption as a result of human activities, and to identify areas for conservation is a common practice (e.g., Hecnar and McCloskey 1996; Pearman 1997; Hager 1998; Welsh and Ollivier 1998; Lawler et al. 2003; Moore et al. 2003; Wilson and McCranie 2003, 2004; Pineda et al. 2005; Kavanagh and Stanton 2005). The practice has particular significance as amphibian populations are declining at several locations worldwide (Richards et al. 1993; Stebbins and Cohen 1995; Laurance et al. 1996; Lips 1998, 1999; Lips et al. 2003; Lips and Donnelly 2005; Pounds et al. 2006; Whitfield et al. 2007; Lips et al. 2008). Habitat loss, global climate change, pollutants, infectious diseases, overexploitation and other processes are driving amphibian species towards extinction (Collins and Storfer 2003; Stuart et al., 2004). A community-wide decline in populations of terrestrial amphibians and common lizards has been reported from La Selva (Whitfield et al. 2007), but it is not known if swamp-breeding hylids display a similar trend of decline. Long-term monitoring of amphibian communities is necessary to detect declines in certain regions of the New World tropics. For this purpose, data on hylid frog abundance collected at the Research Swamp in 1982-83, 1994-95, 2005, and 2011 were compared to identify if changes to the relative abundance of hylid frogs at the site have occurred and if the changes are indicative of population declines. 
The objective of my study was to test the following hypotheses:

$\mathrm{Ha}_{1}$ : Hylid frog species composition at the Research and Cantarana swamps exhibits spatial variation.

$\mathrm{Ha}_{2}$ : Hylid frog species composition at the Research Swamp exhibits temporal variation.

$\mathrm{Ha}_{3}$ : Habitat use varies among species and between swamps.

Ha 4 : Hylid frog abundance at each swamp is correlated with precipitation.

$\mathrm{Ha}_{5}$ : The relative abundance of hylid frogs at the Research Swamp has declined over time.

\section{METHODS}

\section{Study Location}

The La Selva Biological Station is a private biological reserve located a few kilometers from the town of Puerto Viejo de Sarapiquí in Heredia province, northeastern Costa Rica $\left(10^{\circ} 26^{\prime}\right.$ N, $83^{\circ} 59^{\prime}$ W). La Selva is located at the junction between the foothills of the central volcanic mountain chain of Costa Rica and the Caribbean coastal plain, at the confluence of the Sarapiquí and Puerto Viejo rivers (McDade and Hartshorn 1994). The reserve encompasses 1,536 ha of Atlantic lowland forest, of which approximately $62 \%$ is old-growth, $11 \%$ is secondary forest, and the remaining area is composed mostly of abandoned pastures and plantations (McDade and Hartshorn 1994). La Selva became a protected natural preserve in 1968 when the Organization for Tropical Studies (OTS) purchased the original 587 ha of land from the tropical forester, Dr. Leslie Holdridge (McDade and Hartshorn 1994). Subsequent purchases of the lands surrounding 
the original parcel nearly tripled the size of the preserve and connected it on the south end to the Braulio Carrillo National Park, a 47,753 ha park encompassing the high forestcovered volcanic mountains of the Cordillera Central (McDade and Hartshorn 1994).

The climate at La Selva is typical of Atlantic tropical wet forests and is characterized by a bimodal distribution in precipitation, with peaks occurring in JuneAugust and October-December, when more than $400 \mathrm{~mm}$ of rain falls per month (Sanford et al. 1994). The period from February-April is the driest, and March is typically the driest month (Sanford et al. 1994). La Selva receives an average of $4000 \mathrm{~mm}$ of rain annually, with no month receiving less than $100 \mathrm{~mm}$ (Sanford et al. 1994). The average monthly air temperature at La Selva is $26^{\circ} \mathrm{C}$ and there is little variation among months $\left(<3^{\circ} \mathrm{C}\right)$; the diurnal variation in air temperature $\left(6^{\circ}-12^{\circ} \mathrm{C}\right)$ exceeds the monthly variation (Sanford et al. 1994).

\section{Study Sites}

The Research Swamp is located off of the Camino Experimental Sur (near the trail marker located $150 \mathrm{~m}$ from the trail head) within a region of old-growth forest (Figure 1). When full, the Research Swamp pond can measure up to 100 x $60 \mathrm{~m}$ (Strieby 1998). Panicum grande, a tall grass, is the dominant vegetation in the center of the swamp and Spathiphyllum friedrichsthalii, a perennial evergreen herb, is found at the swamp margins. Pentaclethra macroloba and Ficus sp. are the dominant trees found at the edges of the Research Swamp. The Cantarana Swamp is located on the Camino Circular Cercano (near the trail marker located $100 \mathrm{~m}$ from the trail head) in an area of old growth forest that has been set aside as an ecological reserve (Figure 1). The pond can measure up to 70 x 90 m when full (Strieby 1998). Scleria microcarpa, a moderately 
tall grass, dominates the site, mixed with a large population of Spathiphyllum friedrichsthalii and Calyptrocarya poeppigiana. Several trees are also found within the Cantarana Swamp. The Research and Cantarana swamps are located approximately 600 $\mathrm{m}$ apart but the large La Selva laboratory clearing area is located between the swamps.

\section{Sampling}

At the Research Swamp transect lines were established by physically pushing the dense vegetation out of the way. At the Cantarana Swamp the existing $90 \mathrm{~m}$ long boardwalk was used as the transect line. Animals were censused using the Visual Encounter Survey (VES) method described by Crump and Scott (1994). The method entails having two investigators walk the full length of the transect line while searching for animals to a distance of $1 \mathrm{~m}$ on either side of transect. During sampling all hylid frogs observed along the transect were identified to species in the field. Substrate type and height at which animals were found perching were also recorded. The length of time each transect line was sampled was noted. The first transect line censused was alternated to reduce temporal effects. Sampling procedures varied somewhat among sample periods and are described in detail below:

1982-83: Only the Research Swamp was sampled during this period. Sampling was conducted roughly weekly, at night, for 15 months beginning on 23 June 1982 and ending on 31 August 1983 (70 total sampling nights; Table 1). Sampling was started between 19:30 $\mathrm{h}$ and 23:30 $\mathrm{h}$. Two $30 \mathrm{~m}$ transect lines were established; one was located along the shallow margin of the swamp on the western edge and the other through center of the swamp. Spathiphyllum friedrichsthalii dominated the perimeter and Panicum grande 
dominated the center line. These data were collected by Maureen A. Donnelly and Craig Guyer as part of a side project while they were at La Selva conducting their individual doctoral research projects. The results of their hylid surveys were published in Donnelly and Guyer (1994) and in Guyer and Donnelly (2005a).

1994-1995: The Research and Cantarana swamps were sampled weekly, at night, over a period of 18 months from 10 January 1994 to 26 June 1995 (77 total sampling nights; Table 1). During this period the number of investigators varied from two to four, and animals were searched to a distance of $1.5 \mathrm{~m}$ on either side of the transect line. Sampling was started between 20:00 $\mathrm{h}$ and 23:00 $\mathrm{h}$. At the Research Swamp sampling was conducted from a boardwalk that was built through the center of the swamp prior to 1994 . At the beginning of the 2005 sampling period, the boardwalk had fallen into disrepair and no longer existed. These data were collected as part of a monitoring program on amphibian declines in Costa Rica (unpublished data).

2005: The swamps were sampled nightly a total of 33 times, beginning between $20: 30 \mathrm{~h}$ and 22:30 h, from 20 June to 26 July 2005 (Table 1 ). To my knowledge this is the first study of species composition of adult Neotropical anurans in swamps to sample at this fine scale of resolution (nightly). Sampling at the Research Swamp was conducted from a $60 \mathrm{~m}$ long transect line established through the center of the swamp (forest margins did not allow for a longer transect). Two investigators conducted the sampling on most nights. I collected these data as part of a project sponsored by the National Science Foundation's Research Experience for Undergraduates program.

2011: The Research and Cantarana swamps were sampled nightly a total of 37 times, starting between 19:30 $\mathrm{h}$ and 24:00 h, from 17 June to 31 July 2011 (Table 1). The 
transect line established at the Research Swamp followed roughly the same path and was the same length as in 2005. During this period only one investigator conducted sampling on most nights. At the Research Swamp, I (the single investigator) looked to one side, then the other, of the transect line after taking each step. I felt this procedure to be equivalent to having two investigators separately looking to the right and left sides of the transect line. At the Cantarana Swamp I first sampled the area on one side of the boardwalk, then the other. The first side sampled was alternated each night to reduce temporal effects.

\section{Data Analysis}

\section{Spatial variation in species composition}

Species composition is defined in this study as the relative abundance and identity of all hylid frog species encountered at each swamp during each sampling event. The relative abundance of all hylid frog species was pooled together for each day within each sampling month and represents one sampling unit; the set of sampling units from each swamp represents a sampling group. Because the frequency and timing of sampling differed between 1994-95 (weekly, wet and dry seasons) and 2005 and 2011 (nightly, wet season only), analyses were performed separately on data from each sampling period. Analysis of Similarity (ANOSIM) was used to test whether there was a significant difference in species composition between the two swamps. The ANOSIM calculates the dissimilarity between every pair of replicates, within and among the sample groups using the Bray-Curtis similarity coefficient (Bray and Curtis 1957); if two groups of sampling units are different in their species composition, then compositional dissimilarities between the groups will be greater than those within the groups (Clarke 1993). Analysis 
of Similarity is derived from the $R$ statistic [the difference of mean ranks between groups $(r B)$ and within groups $(r W): R=(r B-r W) /(n(n-1) / 4)]$. The value of $R$ ranges from 1.0 to +1.0 : if $R \sim 0$ then there is no difference among groups; if $R>0$ then the groups have different species composition. The statistical significance for ANOSIM $R$ is assessed by randomly permutting the grouping vector ( $\geq 1000$ times) to compute $R^{*}$ and checking whether $R^{*}$ is $\geq R$; the p-value $=$ proportion of $R^{*}$ values that are $\geq R$ (Clarke 1993). Non-metric multi-dimensional scaling plots (nMDS) were constructed to visualize differences in species composition between the swamps. Multi-dimensional scaling is an ordination technique derived from a similarity (or dissimilarity) data matrix among samples that is used to create a plot of the relative similarity (or dissimilarity) of the samples. The distance between points in a nMDS plot is proportional to the similarity of the samples in the original matrix (i.e., the closer two points are in a plot, the more similar they are to each other; Clarke 1993). Therefore, in nMDS plots, if the swamps have great spatial variation in species composition, their samples (represented by points on the plot) will be plotted as two separate clusters; if there is little spatial variation in species composition between the swamps then their samples will be plotted as one cloud of points. I also reduced the abundance data to incidence (presence/absence) data and used ANOSIM and nMDS to test for a difference in species composition between the swamps. Data were reduced to down-weigh the contribution of the common species to the similarity (or dissimilarity) calculation, shifting the emphasis towards patterns in the less common and rare species (Clarke and Warwick 2001). Whenever a significant difference in species composition between two groups was observed, I used the SIMPER ('similarity percentages') routine to examine the percentage contributions of each species 
to the dissimilarity between groups. The SIMPER analysis decomposes the average BrayCurtis dissimilarities between all pairs of samples, one from each group, into percentage contributions from each species (Clark and Gorley 2006). The statistical program PRIMER ${ }^{\circledR}$ V.6 (Plymouth Marine Laboratories, UK) was used to perform the analyses.

\section{Temporal variation in species composition}

I used ANOSIM to test if there was a significant difference in hylid frog species composition at the Research Swamp between the 1982 and 1994 wet seasons (only samples collected between May and December were analyzed) and between 2005 and 2011. Because Donnelly and Guyer (1994) found seasonal differences in hylid frog abundance at the Research Swamp, I analyzed only wet season data to avoid any seasonal effects. I used nMDS plots to visualize dissimilarity in species composition between years and SIMPER to examine the contribution of individual species to the dissimilarity observed. The analyses were carried out in PRIMER ${ }^{\circledR}$ v.6.

\section{Comparison of species composition across time and space}

To examine if hylid frog species composition varied to a greater extent over time or over space, I used ANOSIM and nMDS to compare the species composition of hylid frogs in the Cantarana and Research Swamps in 2005 and 2011. The Global $R$ values generated for pairwise tests between groups were then evaluated to infer a general pattern. 


\section{Patterns of habitat utilization}

Substrate use - To examine differences in substrate use among hylid frogs, I used a $G$-test for independence to determine if the distributions differ across substrate types. The $G$-test examines whether choice of substrate use is independent of species by comparing the frequencies of one nominal variable (i.e., species) for different values of a second nominal variable (i.e., substrate type). Data were pooled from all years sampled at each swamp and compared. Because of sample size constraints I limited the analyses to those hylid species observed more than 30 times at each swamp. These analyses were performed in Microsoft Excel ${ }^{\circledR} 2007$ (Microsoft Corporation).

Perch height - Because perch height data were not normally distributed I used a Kruskal-Wallis test to examine differences in perch height among hylid frog species at each swamp. I used a post-hoc Mann-Whitney test to identify species that differed from each other in perch height, and also to compare perch height for each species between the two swamps. Data were pooled and analyses were limited to abundant species as described above. Analyses were performed using SPSS ${ }^{\circledR}$ v.18 (IBM Corporation).

\section{Relationship between rainfall and hylid frog abundance}

I used Analysis of Variance (ANOVA) to determine the significance of the effect of precipitation on the relative abundance of hylids frogs at each swamp separately for each year sampled. I log-transformed the abundance data from all years except 1982 prior to analyses because they were not normally distributed. I used linear regression to quantify the effect of precipitation on individual relative abundance and to allow for comparison between the swamps. Daily precipitation $(\mathrm{mm})$ data were collected on site at 
La Selva Biological Station and are available for all years, beginning in 1982. I performed these analyses in Microsoft Excel $^{\circledR} 2007$.

\section{Hylid frog relative abundance over time}

The relative abundance of a hylid frog species on a sampling event was expressed in terms of catch-per-unit-effort (CPUE; number of frogs caught/person-hour of search). I analyzed wet season data only to avoid any seasonal effects on hylid frog abundance. After discarding dry season data and data with no person-hour of search data available, only $A$. callidryas and D. ebraccatus had sufficient non-zero CPUE data points ( $>3$ per year) to allow for valid comparisons. I compared hylid frog CPUE between 1982 and 1994 separately from 2005 and 2011 because for the first two years data were collected during the entire wet season (May-December) approximately weekly and for the last two years data were collected only in June-July and on a nightly basis. I used Mann-Whitney tests to compare CPUE between pairs of years because the data were not normally distributed. The analyses were performed in $\operatorname{SPSS}^{\circledR}$ v.18.

\section{RESULTS}

\section{General patterns of abundance and richness}

The Research and Cantarana Swamps were sampled a total of 364 times combined during the course of this study (Table 2). Across all swamps and all years, 8101 hylid frogs were encountered (Table 3). A comparable number of frogs were encountered between the two swamps, even though the Research Swamp was sampled 70 
more times than the Cantarana. The swamps shared the same species except for $S$. sordida which was never encountered at the Cantarana. Overall, S. elaeochrous, D. ebraccatus, and $A$. callidryas were the most abundant species, and two of these species were always the top two most abundant species across all swamps and years, except at the Research Swamp in 1994 (Table 3).

\section{Spatial variation in species composition}

Hylid frog species composition did not differ significantly between the Cantarana and Research swamps during 1994-95 (ANOSIM, Global $R=0.068, \mathrm{P}=0.001$; Fig. 2). For these analyses I grouped Agalychnis callidryas and A. saltator into Agalychnis spp. because there was a large number $(\mathrm{n}=460)$ of Agalychnis individuals in the Cantarana Swamp that could not be identified to species. I re-tested the data with all Agalychnis spp. individuals removed and only those Agalychnis individuals identified to species left in the matrix and the result was not significant (data not shown). Species composition was also not significantly different between the swamps in 2005 (ANOSIM, Global $R=0.024, \mathrm{P}=$ 0.120; Fig. 2). In 2011 species composition was significantly different between the swamps as both the abundance (ANOSIM, Global $R=0.280, \mathrm{P}=0.001$; Fig. 2) and presence/absence (not shown) matrices were effective at discriminating between swamps. The SIMPER analysis revealed that the total average dissimilarity in hylid species composition between the swamps was $80 \%$ in 2011. Scinax elaeochrous accounted for close to $40 \%$ of the total average dissimilarity between swamps and was almost five times more abundant in the Cantarana than in the Research Swamp in 2011 (Table 4). Dendropsophus ebraccatus was the second most discriminating species in 2011, 
contributing $24 \%$ to the total average dissimilarity between swamps and was over 60 times more abundant in the Cantarana (Table 4). Agalychnis callidryas was the next most discriminating species and contributed close to $20 \%$ to the total average dissimilarity between swamps and was almost two times more abundant at the Research Swamp compared to the Cantarana (Table 4). Together the three species contributed close to $80 \%$ to the total average dissimilarity between swamps.

\section{Temporal variation in species composition}

Hylid frog species composition at the Research Swamp was significantly different between 1982 and 1994 as confirmed by both the abundance (ANOSIM, Global $R=$ 0.340, $\mathrm{P}=0.001 ;$ Fig. 3 ) and presence/absence matrices (data not shown). The SIMPER results indicate that species composition was $80 \%$ different between years (Table 5). Scinax elaeochrous contributed $30 \%$ to the total average dissimilarity between years, and Agalychnis spp. and D. ebraccatus contributed 22 and 20 percent, respectively (Table 5). Hylid frog species composition at the Research Swamp was also significantly different between 2005 and 2011 for both the abundance (ANOSIM, Global $R=0.238, \mathrm{P}=0.001$; Fig. 3) and presence/absence matrices (not shown). Agalychnis callidryas and $S$. elaeochrous were the top two contributing species to the average dissimilarity between the years (over $60 \%$ combined, Table 5 ). The total average dissimilarity between years was $80 \%$ (Table 5). 
Comparison of species composition across time and space

Hylid frog species composition varied significantly between swamps and years in 2005 and 2011 (ANOSIM, Global $R=0.242, \mathrm{P}=0.001$; Fig. 6). Pairwise tests revealed that temporal turnover in the hylid assemblage was more consistent than spatial turnover, as species composition differed significantly between different years at the same swamp at both the Research and Cantarana swamps, but was only significantly different between different swamps during the same year in 2011 (Table 6).

\section{Patterns of habitat utilization}

Substrate use - Hylid frogs used eight substrate categories during the study (Table 7); the most commonly used included the most abundant plants in the swamps, aroids and graminoids. The use of perch substrates varied among species at the Cantarana Swamp $(G=504.057, \mathrm{df}=14, \mathrm{P}<0.001)$ and at the Research Swamp $(G=931.640, \mathrm{df}=14, \mathrm{P}<$ 0.001). Most hylids were found on grass (Table 7).

Perch height - Hylids at the Cantarana Swamp differed significantly in mean rank of perch height $\left(\chi_{7,2705}^{2}=432.35, \mathrm{P}<0.001\right)$. Post-hoc Mann-Whitney tests on differences in perch height indicated that the two Agalychnis species did not differ significantly from each other, the two Dendropsophus species did not differ significantly in from each other, the two Scinax species did not differ significantly from each other, and $D$. phlebodes and $T$. loquax did not differ significantly from each other. Hylids at the Research Swamp also differed significantly in mean rank of perch height $\chi_{7,2952}^{2}=$ 449.29, $\mathrm{P}<0.001)$. Post-hoc Mann-Whitney tests on differences in perch height indicated that $S$. boulengeri did not differ significantly from S. elaeochrous, D. ebraccatus, or $T$. 
loquax, and that $T$. loquax did not differ significantly from $D$. phlebodes. Mann-Whitney tests for differences in mean rank of perch height for each hylid species between the two swamps revealed that only $S$. boulengeri and S. baudinii did not differ significantly in perch height between swamps.

\section{Relationship between rainfall and hylid frog relative abundance}

In 1982 and 1994 total rainfall was lower than average during the dry season, and the dry season was one month longer than average (Fig. 5). The wet season was wetter than average during both years, except November and December 1982 were average and October 1994 was drier than average (Fig. 5). The 1982 wet season coincided with the 1982-83 El Niño-Southern Oscillation event, one of the most severe disturbances of its kind ever recorded (Philander 1983; Glynn 1988), and it is possible that the event had an effect on the rainfall patterns observed in 1982. In 2005 the early wet season (MayAugust) was dryer than average. June of 2005 was the driest June on record (205 mm of rain; Fig. 6). During the early 2011 wet season, July and August were drier than average (Fig. 6).

Hylid frog relative abundance in the wet season varied with rainfall for only three of the relationships tested. Rainfall had a positive effect on hylid relative abundance at the Research Swamp in $1982\left(R^{2}=0.2567 ; \mathrm{P}=0.002\right.$; Fig. 7), at the Research Swamp in $2005\left(R^{2}=0.1789 ; \mathrm{P}=0.025 ;\right.$ Fig. 7 $)$ and at the Cantarana Swamp in $2011\left(R^{2}=0.2560\right.$; $\mathrm{P}=0.003$; Fig. 7). 


\section{Hylid frog relative abundance over time}

There was no significant difference in A. callidryas CPUE at the Research Swamp between the 1982 and 1994 wet seasons $(U=192.000, \mathrm{P}=0.098)$ or between the 2005 and 2011 wet seasons $(U=393.500, \mathrm{P}=0.841)$. Dendropsophus ebraccatus $\mathrm{CPUE}$ was not significantly different at the Research Swamp between 1982 and $1994(U=179.500$, $\mathrm{P}=0.105)$, but CPUE increased significantly $(\mathrm{U}=197.000, \mathrm{P}<0.001)$ between 2005 $($ mean rank $=21.79)$ and $2011($ mean rank $=36.46)$.

\section{DISCUSSION}

Several studies have found geographic distance to be important in structuring amphibian assemblages, with similarity between assemblages increasing with decreasing geographic distance (see Parris 2004, Ernst and Rödel 2005, 2008, Keller et al. 2009, von May et al. 2010). The swamps I studied are located closer to each other $(\sim 600 \mathrm{~m})$ than the closest sites in any of the studies mentioned above, thus falling at the low end of the inter-site distance scale. In accordance with these studies, I found no difference in species composition between the swamps in 1994 and 2005, which indicates that despite the observed differences in local habitat characteristics between the swamps, both sites were favorable to a similar suite of hylids frogs. Additionally, because the swamps are of roughly equivalent size, are embedded within the same forest type, and the intervening matrix appears relatively hospitable to frog movement away from swamps (I spotted several hylids in the forest and in the lab clearing $>150 \mathrm{~m}$ away from the nearest swamp), it is not altogether surprising that species composition was similar at the two 
swamps in 1994 and 2005. In contrast, I found that species composition did differ between the swamps in 2011, and that differences in the abundance of S. elaeochrous and D. ebraccatus between the swamps contributed the most to the pattern I observed. I suggest that changes in local habitat characteristics at either or at both swamps that favored a greater abundance of S. elaeochrous and D. ebraccatus at the Cantarana in 2011 led to a temporal change in spatial similarity between the assemblages. Because both communities and habitats may change over time (Ricklefs and Schulter 1993), and temporal variation in community composition can be attributed to temporal changes in habitat characteristics (Houlahan et al. 2007), it is possible that temporally dynamic systems such as temporary Neotropical forest swamps will at times converge and at times diverge in species composition over time (i.e., change in similarity in species composition between two dynamic swamps located nearby in geographic space over time is a sinusoidal function). That temporal variation in species composition was observed at both the Research and Cantarana swamps lends support to this explanation.

It is also possible, however, that an observed change in vegetation structure at the Research Swamp in 2011 (greater density of $P$. grande than 2005), combined with a smaller number of observers that year ( 1 vs. up to 4 in the previous studies) may have reduced the detectability of treefrogs at the swamp, thereby producing an artificial difference in species composition between the swamps when none existed. Several frogs were heard calling close to the transect line at the Research Swamp in 2011 on nights when few frogs were detected. This observation, combined with the fact that the smallest number of frogs encountered across all swamps and years were encountered at the Research Swamp in 2011, could indicate that sampling was not as effective in capturing 
the actual hylid abundance in the Research Swamp in 2011. Because no vegetation metric, or any other local habitat variable, was measured in any of the study periods, it is difficult to link any of the observed compositional patterns to changes in the local habitat. Additional sampling at both the Research and Cantarana swamps that includes measurements of temporal variation in local habitat variables known to affect the distribution and abundance of anurans would contribute greatly to the interpretation of the patterns I observed.

Closely-related species must exhibit differences in their use of resources sufficient to minimize or avoid competition to allow for co-occurrence (Lack 1944, 1947). At the Cantarana Swamp, congenerics (i.e., Scinax and Dendropsophus) used grass more frequently and were found at similar heights. If space is an important resource partitioned by treefrogs at breeding ponds (Crump 1974, Toft 1985, Donnelly and Guyer 1994), interspecific competition for space may be the force that gave rise to the alternative breeding strategies exhibited by the Scinax species, where $S$. elaeochrous is an explosive breeder and $S$. boulengeri is a prolonged breeder (Donnelly and Guyer 1994). The alternative breeding strategies exhibited by Scinax allows the species to partition habitat temporally, thereby reducing competition and promoting co-occurrence at the swamp. In addition, interspecific competition for limited space may to some extent be responsible for the pattern of abundance observed for the Dendropsophus species, where the species most successful at exploiting a limited resource (i.e., space) is very abundant $(=D$. ebraccatus) and the less successful species is much less common (=D. phlebodes).

At the Research Swamp five hylids, D. ebraccatus, D. phlebodes, S. boulengeri, S. elaeochrous, and T. loquax were found perching most often on grass at similar heights. 
The habitat utilization patterns observed at the Research Swamp may have partially resulted from sampling bias. Sampling at the Research Swamp in 1994-95, 2005, and 2011 was carried out solely from a transect line extending through the middle of the swamp where Panicum grande grows as a monoculture. Treefrogs were observed most often perching on grass at the Research Swamp than at the Cantarana (6 species vs. 4 species, respectively) likely because of a lack of substrate diversity through the majority of the transect line. All five species are small-bodied in comparison to the other three species included in the analysis (A. callidryas, A. saltator, and S. baudinii) and may share some physiological constraint that prevents utilization of higher perches (e.g., low cutaneous resistance to water loss) or some morphological constraint that prevents exploration of lower perches (e.g., size-related vulnerability to predation). Differences in timing of reproduction (Donnelly and Guyer 1994) or relative abundance may be the mechanisms by which these closely-related hylid frogs partition habitat to allow for cooccurrence in the swamps I examined. Ultimately, manipulative experiments are the only way to test this hypothesis, and until then any conclusion reached solely through observation must be drawn with caution.

Contrary to my prediction, hylid frog abundance was correlated with rainfall in only three of the seven relationships tested. Treefrogs at the Research and Cantarana swamps responded to rainfall in different ways over the course of the study. During the 1982 wet season frogs at the Research Swamp were often most abundant on the rainiest nights, but no such pattern was observed there during the 1994 wet season. Both the 1982 and 1994 study periods coincided with ENSO events, and rainfall was not significantly different between the 1982 and 1994 wet seasons. It may be possible that changes in local 
habitat conditions at the Research Swamp between 1982 and 1994, such as longer pond hydroperiod leading to a more stable breeding habitat, caused rainfall to not be a factor affecting treefrog abundance at the Research Swamp in the wet season of 1994.

In 2005 water levels at the Research and Cantarana swamps were low for the duration of the study, but at the Research Swamp water was retained for longer after rain events (personal observation), likely as a result of the Research Swamp's lower elevation. It is possible that treefrogs did not respond to rainfall in the Cantarana in 2005 because the swamp never filled enough and/or for long enough to elicit a strong response to aggregate to breed. Different water retention times between the swamps may also be responsible for explaining the pattern observed in 2011. Because water at the Cantarana likely drains faster than at the Research Swamp, pools of standing water were more temporary in the Cantarana, causing treefrogs there to take advantage of pools created during actual rain events to breed. Treefrogs at the Research Swamp had pools available to them for longer and could therefore breed over an extended period of time. Because rainfall is more or less steady during the wet season at La Selva, it is not surprising that variation in rainfall did not explain or explained a modest amount (18$26 \%$ ) of the variation in hylid frog abundance observed across all swamps and years.

I found no indication of decline in the relative abundance of $A$. callidryas and $D$. ebraccatus at the Research Swamp, indicating that their populations are either stable or increasing at this site. Because for the most part the data analyzed in this project were not collected with the intention of evaluating trends in relative abundance of populations over time, any conclusions based on these analyses must be made with caution. 
In conclusion, my study stresses the importance of including multiple breeding seasons in monitoring studies of amphibians in order to capture the temporal dynamism of assemblages and to assess the complete diversity associated with a swamp. It is also important to include measurements of fluctuating habitat variables collected over time to disentangle the relative contributions of space and time to patterns of species composition in studies where multiple sites are under investigation. 


\section{LITERATURE CITED}

Bray, J.R. and J.T. Curtis. 1957. An ordination of the upland forest communities of Southern Wisconsin. Ecological Monographs 27: 325-349.

Clarke, K.R. 1993. Non-parametric multivariate analysis of changes in community structure. Australian Journal of Ecology 18: 117-143.

Clarke, K.R. and R.N. Gorley. 2006. PRIMER v6: User Manual/Tutorial. PRIMER-E, Plymouth.

Clarke, K.R. and R.M. Warwick. 2001. Change in marine communities: an approach to statistical analysis and interpretation, $2^{\text {nd }}$ edition. PRIMER-E, Plymouth.

Collins, J.P. and A. Storfer. 2003. Global amphibian declines: sorting the hypotheses. Diversity and Distributions 9: 89-98.

Crump, M.L. 1974. Reproductive strategies in a tropical anuran community. University of Kansas Museum of Natural History Miscellaneous Publication. 61: 1-68.

Crump, M.L. and N.J. Scott. 1994. Visual encounter surveys. Pages 84-91 in W.R. Heyer, M.A. Donnelly, R.W. McDiarmid, L.C. Hayek, and M.S. Foster, eds. Measuring and monitoring biological diversity: Standard methods for amphibians. Smithsonian Institution Press, Washington, D.C.

Donnelly, M.A. and C. Guyer. 1994. Patterns of reproduction and habitat use in an assemblage of Neotropical hylid frogs. Oecologia 98: 291-302.

Ernst, R. and M.-O. Rödel. 2005. Anthropogenically induced changes of predictability in tropical anuran assemblages. Ecology 86: 3111-3118.

Ernst, R. and M.-O. Rödel. 2008. Patterns of community composition in two tropical tree frog assemblages: separating spatial structure and environmental effects in disturbed and undisturbed forests. Journal of Tropical Ecology 24: 111-120.

Guyer, C. and M.A. Donnelly. 2005. Patterns of co-occurrence of hylid frogs at a temporary wetland in Costa Rica. Pages 227-242 in M.A. Donnelly, B.I. Crother, C. Guyer, M.H. Wake and M.E. White, eds. Ecology and Evolution in the Tropics: A Herpetological Perspective. The University of Chicago Press, Chicago.

Hecnar, S.J. and R.T. McCloskey. 1996. Regional dynamics and the status of amphibians. Ecology 77: 2091-2097. 
Houlahan, J.E., D.J Currie, K. Cottenie, G.S. Cumming, S.K.M. Ernest, C.S. Findlay, S.D. Fuhlendorf, U. Gaedke, P. Legendre, J.J. Magnuson, B.H. McArdle, E.H. Muldavin, D. Noble, R. Russell, R.D. Stevens, T.J. Willis, I.P. Woiwod and S.M. Wondzell. 2007. Compensatory dynamics are rare in natural ecological communities. Proceedings of the National Academy of Sciences of the United States of America 104: 3273-3277.

Kavanagh, R.P. and M.A. Stanton. 2005. Vertebrate species assemblages and species sensitivity to logging in the forests of north-eastern New South Wales. Forest Ecology and Management 209: 309-341.

Keller, A., M.-O. Rödel, K.E. Linsenmair and T.U. Grafe. 2009. The importance of environmental heterogeneity for species diversity and assemblage structure in Bornean stream frogs. Journal of Animal Ecology 78: 305-314.

Lack, D. 1944. Ecological aspects of species formation in passerine birds. Ibis 86: 260286.

Lack, D. 1947. Darwin's Finches. Cambridge University Press, Cambridge, UK.

Laurance, W.F., K.R. McDonald and R. Speare. 1996. Epidemic disease and the catastrophic decline of Australian rain forest frogs. Conservation Biology 10: 406-413.

Lawler, J.J., D. White, J.C. Sifneos and L.L. Master. 2003. Rare species and the use of indicator groups for conservation planning. Conservation Biology 17: 875-882.

Lips, K.R. 1998. Decline of a tropical montane amphibian fauna. Conservation Biology 12: $106-117$.

Lips, K.R. 1999. Mass mortality and population declines of anurans at an upland site in western Panama. Conservation Biology 13: 117-125.

Lips, K.R., J. Diffendorfe, J.R. Mendelson and M. Sears. 2008. Riding the wave: Climate change, emerging infectious disease and amphibian declines. PLOS Biology 6: 441-454.

Lips, K.R. and M.A. Donnelly. 2005. Lessons from the Tropics. Pages 198-205 in M. Lannoo, ed. Amphibian declines: The conservation status of United States species. University of California Press, Berkeley.

Lips, K.R., D.E. Green and R. Papendick. 2003. Chytridiomycosis in wild frogs from southern Costa Rica. Journal of Herpetology 37: 215-218. 
McDade, L. A., and G. S. Hartshorn. 1994 La Selva Biological Station in L.A. McDade, K.S. Bawa, H.A. Hespendeide and G.S. Hartshorn, eds. La Selva: Ecology and natural history of a Neotropical rain forest. The University of Chicago Press, Chicago.

Moore, J.L., A. Balmford, T. Brooks, N.D. Burgess, L.A. Hansen, C. Rahbek and P.H. Williams. 2003. Performance of Sub-Saharan vertebrates as indicator groups for identifying priority areas for conservation. Conservation Biology 17: 207-218.

Parris, K.M. 2004. Environmental and spatial variables influence the composition of frog assemblages in sub-tropical eastern Australia. Ecography 27: 392-400.

Pearman, P.B. 1997. Correlates of amphibian diversity in an altered landscape of Amazonian Ecuador. Conservation Biology 11: 1211-1225.

Pineda, E., C. Moreno, F. Escobar and G. Halffter. 2005. Frog, bat, and dung beetle diversity in the cloud forest and coffee agroecosystems of Veracruz, Mexico. Conservation Biology 19: 400-410.

Pounds, J.A., M.R. Bustamante, L.A. Coloma, J.A. Consuegra, M.P.L. Fogden, P.N. Foster, E. La Marca, K.L. Masters, A. Merino-Viteri, R. Puschendorf, S.R. Ron, G.A. Sanchez-Azofeifa, C.J. Still and B.E. Young. 2006. Widespread amphibian extinctions from epidemic disease driven by global warming. Nature 439: 161167.

Richards, S.J., K.R. McDonald and R.A. Alford. 1993. Declines in populations of Australia's endemic tropical rainforest frogs. Pacific Conservation Biology 1: 6677.

Ricklefs, R.E. and D. Schluter. 1993. Species diversity in ecological communities: Historical and geographic perspectives. The University of Chicago Press, Chicago.

Sanford, R.L., Jr., P. Paaby, J.C. Luvall and E. Phillips. 1994. Climate, geomorphology, and aquatic systems. Pages 19-33 in L.A. McDade, K.S. Bawa, H.A.

Hespendeide and G.S. Hartshorn, eds. La Selva: Ecology and natural history of a Neotropical rain forest. The University of Chicago Press, Chicago.

Stebbins, R.C. and N.W. Cohen. 1995. A natural history of amphibians. Princeton University Press, Princeton, New Jersey.

Strieby, A.M. 1998. A multispecific frog chorus: calls, calling sites, and acoustical interference in a complex forest habitat. Thesis. M.Sc. in Biology. California State University at Northridge. 
Stuart, S.N., J.S. Chanson, N.A. Cox, B.E. Young, A.S.L. Rodrigues, D.L. Fischman and R. W. Waller. 2004. Status and trends of amphibian declines and extinctions worldwide. Science 306: 1783-1786.

Toft, C.A. 1985. Resource partitioning in amphibians and reptiles. Copeia 1985: 1-112.

von May, R., J.M. Jacobs, R. Santa-Cruz, J. Valdivia, J.M. Huaman, and M.A. Donnelly. 2010. Amphibian community structure as a function of forest type in Amazonian Peru. Journal of Tropical Ecology 26: 509-519.

Welsh, H.H., Jr. and L.M. Ollivier. 1998. Stream amphibians as indicators of ecosystem stress: a case study from California's redwoods. Ecological Applications 8: 1118-1132.

Whitfield, S.M., K.E. Bell, T. Philippi, M. Sasa, F. Bolaños, G. Chaves, J.M. Savage and M.A. Donnelly. 2007. Amphibian and reptile declines over 35 years at La Selva, Costa Rica. Proceedings of the National Academy of Sciences USA 104(20): 8352-8356.

Wilson, L.D. and J.R. McCraine. 2003. Herpetofauna indicator species as measures of environmental stability in Honduras. Caribbean Journal of Science 39: 50-67.

Wilson, L.D. and J.R. McCraine. 2004. The conservation status of the herpetofauna of Honduras. Amphibian and Reptile Conservation 3: 6-33. 
Table 1. Sampling scheme.

\begin{tabular}{|c|c|c|c|c|c|c|}
\hline \multirow{2}{*}{$\begin{array}{c}\text { Sample } \\
\text { period }\end{array}$} & \multicolumn{2}{|c|}{ Swamp(s) sampled } & \multirow{2}{*}{$\begin{array}{l}\text { Sampling } \\
\text { frequency }\end{array}$} & \multirow[b]{2}{*}{ Start date } & \multirow[b]{2}{*}{ End date } & \multirow{2}{*}{$\begin{array}{c}\text { No. of } \\
\text { samples }\end{array}$} \\
\hline & Research & Cantarana & & & & \\
\hline $1982-1983$ & $\mathrm{x}$ & & weekly & 23-Jun-82 & 31-Aug-83 & 70 \\
\hline 1994-1995 & $\mathrm{x}$ & $\mathrm{x}$ & weekly & 10-Jan-94 & 26-Jun-95 & 77 \\
\hline 2005 & $\mathrm{x}$ & $\mathrm{x}$ & nightly & 13-Jun-05 & 26-Jul-05 & $33 *$ \\
\hline 2011 & $\mathrm{x}$ & $\mathrm{x}$ & nightly & 17-Jun-11 & 31-Jul-11 & 37 \\
\hline
\end{tabular}

* The Cantarana Swamp was sampled 33 times in 2005; the Research Swamp was sampled only 32 times. 
Table 2. The date and study day number for the 1982-83, 1994-95, 2005 and 2011 sample periods.

\begin{tabular}{|c|c|c|c|c|c|c|c|}
\hline \multicolumn{2}{|c|}{$1982-1983$} & \multicolumn{2}{|c|}{ 1994-1995 } & \multicolumn{2}{|c|}{2005} & \multicolumn{2}{|c|}{2011} \\
\hline Date & Day No. & Date & Day No. & Date & Day No. & Date & Day No. \\
\hline 23 June 1982 & 1 & 10 January 1994 & 1 & *13 June 2005 & 1 & 17 June 2011 & 1 \\
\hline 29 June 1982 & 7 & 17 January 1994 & 8 & 14 June 2005 & 2 & 18 June 2011 & 2 \\
\hline 7 July 1982 & 9 & 7 February 1994 & 29 & 15 June 2005 & 3 & 19 June 2011 & 3 \\
\hline 14 July 1982 & 15 & 21 February 1994 & 43 & 20 June 2005 & 8 & 20 June 2011 & 4 \\
\hline 20 July 1982 & 22 & 28 February 1994 & 50 & 21 June 2005 & 9 & 21 June 2011 & 5 \\
\hline 26 July 1982 & 28 & 7 March 1994 & 57 & 22 June 2005 & 10 & 22 June 2011 & 6 \\
\hline 3 August 1982 & 34 & 13 March 1994 & 63 & 23 June 2005 & 11 & 23 June 2011 & 7 \\
\hline 10 August 1982 & 42 & 20 March 1994 & 70 & 24 June 2005 & 12 & 24 June 2011 & 8 \\
\hline 17 August 1982 & 49 & 28 March 1994 & 78 & 26 June 2005 & 14 & 25 June 2011 & 9 \\
\hline 24 August 1982 & 56 & 4 April 1994 & 85 & 27 June 2005 & 15 & 26 June 2011 & 10 \\
\hline 25 August 1982 & 64 & 11 April 1994 & 92 & 29 June 2005 & 17 & 28 June 2011 & 12 \\
\hline 26 August 1982 & 70 & 18 April 1994 & 99 & 30 June 2005 & 18 & 29 June 2011 & 13 \\
\hline 31 August 1982 & 77 & 25 April 1994 & 106 & 2 July 2005 & 20 & 30 June 2011 & 14 \\
\hline 7 September 1982 & 84 & 2 May 1994 & 113 & 3 July 2005 & 21 & 1 July 2011 & 15 \\
\hline 14 September 1982 & 92 & 9 May 1994 & 120 & 4 July 2005 & 22 & 2 July 2011 & 16 \\
\hline 22 September 1982 & 99 & 16 May 1994 & 127 & 6 July 2005 & 24 & 3 July 2011 & 17 \\
\hline 29 September 1982 & 102 & 23 May 1994 & 134 & 7 July 2005 & 25 & 6 July 2011 & 20 \\
\hline 2 October 1982 & 103 & 30 May 1994 & 141 & 11 July 2005 & 29 & 8 July 2011 & 22 \\
\hline 3 October 1982 & 104 & 6 June 1994 & 148 & 12 July 2005 & 30 & 13 July 2011 & 27 \\
\hline 4 October 1982 & 105 & 13 June 1994 & 155 & 13 July 2005 & 31 & 14 July 2011 & 28 \\
\hline 5 October 1982 & 112 & 20 June 1994 & 162 & 14 July 2005 & 32 & 15 July 2011 & 29 \\
\hline 12 October 1982 & 119 & 27 June 1994 & 169 & 15 July 2005 & 33 & 16 July 2011 & 30 \\
\hline 19 October 1982 & 124 & 4 July 1994 & 176 & 16 July 2005 & 34 & 17 July 2011 & 31 \\
\hline 24 October 1982 & 126 & 11 July 1994 & 183 & 17 July 2005 & 35 & 18 July 2011 & 32 \\
\hline
\end{tabular}




\begin{tabular}{|c|c|c|c|c|c|c|c|}
\hline \multicolumn{2}{|c|}{$1982-1983$} & \multicolumn{2}{|c|}{ 1994-1995 } & \multicolumn{2}{|c|}{2005} & \multicolumn{2}{|c|}{2011} \\
\hline Date & Day No. & Date & Day No. & Date & Day No. & Date & Day No. \\
\hline 26 October 1982 & 133 & 18 July 1994 & 190 & 18 July 2005 & 36 & 19 July 2011 & 33 \\
\hline 2 November 1982 & 140 & 25 July 1994 & 197 & 19 July 2005 & 37 & 20 July 2011 & 34 \\
\hline 9 November 1982 & 147 & 1 August 1994 & 204 & 20 July 2005 & 38 & 21 July 2011 & 35 \\
\hline 16 November 1982 & 154 & 8 August 1994 & 211 & 21 July 2005 & 39 & 22 July 2011 & 36 \\
\hline 23 November 1982 & 161 & 15 August 1994 & 218 & 22 July 2005 & 40 & 23 July 2011 & 37 \\
\hline 30 November 1982 & 168 & 22 August 1994 & 225 & 23 July 2005 & 41 & 24 July 2011 & 38 \\
\hline 7 December 1982 & 177 & 29 August 1994 & 232 & 24 July 2005 & 42 & 25 July 2011 & 39 \\
\hline 16 December 1982 & 182 & 4 September 1994 & 238 & 25 July 2005 & 43 & 26 July 2011 & 40 \\
\hline 21 December 1982 & 189 & 12 September 1994 & 246 & 26 July 2005 & 44 & 27 July 2011 & 41 \\
\hline 28 December 1982 & 195 & 19 September 1994 & 253 & & & 28 July 2011 & 42 \\
\hline 12 January 1983 & 204 & 26 September 1994 & 260 & & & 29 July 2011 & 43 \\
\hline 19 January 1983 & 211 & 3 October 1994 & 267 & & & 30 July 2011 & 44 \\
\hline 25 January 1983 & 217 & 10 October 1994 & 274 & & & 31 July 2011 & 45 \\
\hline 1 February 1983 & 224 & 17 October 1994 & 281 & & & & \\
\hline 8 February 1983 & 231 & 24 October 1994 & 288 & & & & \\
\hline 15 February 1983 & 238 & 31 October 1994 & 295 & & & & \\
\hline 22 February 1983 & 245 & 7 November 1994 & 302 & & & & \\
\hline 1 March 1983 & 252 & 14 November 1994 & 309 & & & & \\
\hline 8 March 1983 & 259 & 21 November 1994 & 316 & & & & \\
\hline 15 March 1983 & 266 & 28 November 1994 & 323 & & & & \\
\hline 22 March 1983 & 273 & 5 December 1994 & 330 & & & & \\
\hline 29 March 1983 & 280 & 12 December 1994 & 337 & & & & \\
\hline 5 April 1983 & 287 & 19 December 1994 & 344 & & & & \\
\hline 12 April 1983 & 294 & 26 December 1994 & 351 & & & & \\
\hline 19 April 1983 & 301 & 2 January 1995 & 358 & & & & \\
\hline 26 April 1983 & 308 & 9 January 1995 & 365 & & & & \\
\hline
\end{tabular}




\begin{tabular}{|c|c|c|c|c|c|c|c|}
\hline \multicolumn{2}{|c|}{$1982-1983$} & \multicolumn{2}{|c|}{ 1994-1995 } & \multicolumn{2}{|c|}{2005} & \multicolumn{2}{|c|}{2011} \\
\hline Date & Day No. & Date & Day No. & Date & Day No. & Date & Day No. \\
\hline 3 May 1983 & 315 & 16 January 1995 & 372 & & & & \\
\hline 6 May 1983 & 318 & 23 January 1995 & 379 & & & & \\
\hline 8 May 1983 & 320 & 30 January 1995 & 386 & & & & \\
\hline 10 May 1983 & 322 & 6 February 1995 & 393 & & & & \\
\hline 17 May 1983 & 329 & 13 February 1995 & 400 & & & & \\
\hline 24 May 1983 & 336 & 20 February 1995 & 407 & & & & \\
\hline 31 May 1983 & 343 & 27 February 1995 & 414 & & & & \\
\hline 7 June 1983 & 350 & 6 March 1995 & 421 & & & & \\
\hline 15 June 1983 & 358 & 13 March 1995 & 428 & & & & \\
\hline 21 June 1983 & 364 & 20 March 1995 & 435 & & & & \\
\hline 28 June 1983 & 371 & 27 March 1995 & 442 & & & & \\
\hline 5 July 1983 & 378 & 3 April 1995 & 449 & & & & \\
\hline 12 July 1983 & 385 & 10 April 1995 & 456 & & & & \\
\hline 19 July 1983 & 392 & 17 April 1995 & 463 & & & & \\
\hline 26 July 1983 & 399 & 24 April 1995 & 470 & & & & \\
\hline 2 August 1983 & 406 & 1 May 1995 & 477 & & & & \\
\hline 9 August 1983 & 413 & 8 May 1995 & 484 & & & & \\
\hline 16 August 1983 & 420 & 15 May 1995 & 491 & & & & \\
\hline 23 August 1983 & 427 & 22 May 1995 & 498 & & & & \\
\hline \multirow[t]{5}{*}{31 August 1983} & 435 & 29 May 1995 & 505 & & & & \\
\hline & & 5 June 1995 & 512 & & & & \\
\hline & & 12 June 1995 & 519 & & & & \\
\hline & & 19 June 1995 & 526 & & & & \\
\hline & & 26 June 1995 & 533 & & & & \\
\hline
\end{tabular}

* Only the Cantarana Swamp was sampled on this date. 
Table 3. Hylid frogs encountered at the Research and Cantarana swamps during the study.

\begin{tabular}{lrrrrrrrrrr}
\hline & \multicolumn{3}{c}{ Research Swamp } & \multicolumn{4}{c}{ Cantarana Swamp } & \multicolumn{2}{c}{ Grand } \\
\multicolumn{1}{c}{ Taxon } & $\mathbf{1 9 8 2 - 8 3}$ & $\mathbf{1 9 9 4 - 9 5}$ & $\mathbf{2 0 0 5}$ & $\mathbf{2 0 1 1}$ & Total & $\mathbf{1 9 9 4 - 9 5}$ & $\mathbf{2 0 0 5}$ & $\mathbf{2 0 1 1}$ & Total & Total \\
\hline Agalychnis callidryas & 165 & 41 & 95 & 38 & $\mathbf{3 3 9}$ & 12 & 60 & 23 & $\mathbf{9 5}$ & $\mathbf{4 3 4}$ \\
Agalychnis saltator & 53 & 29 & 31 & 2 & $\mathbf{1 1 5}$ & 85 & 38 & 14 & $\mathbf{1 3 7}$ & $\mathbf{2 5 2}$ \\
Agalychnis spp. & 0 & 20 & 5 & 12 & $\mathbf{3 7}$ & 460 & 5 & 1 & $\mathbf{4 6 6}$ & $\mathbf{5 0 3}$ \\
Dendropsophus ebraccatus & 357 & 370 & 92 & 1 & $\mathbf{8 2 0}$ & 1970 & 77 & 79 & $\mathbf{2 1 2 6}$ & $\mathbf{2 9 4 6}$ \\
Dendropsophus phlebodes & 70 & 68 & 4 & 4 & $\mathbf{1 4 6}$ & 27 & 0 & 10 & $\mathbf{3 7}$ & $\mathbf{1 8 3}$ \\
Scinax elaeochrous & 2131 & 52 & 0 & 58 & $\mathbf{2 2 4 1}$ & 639 & 10 & 281 & $\mathbf{9 3 0}$ & $\mathbf{3 1 7 1}$ \\
Scinax boulengeri & 75 & 24 & 1 & 12 & $\mathbf{1 1 2}$ & 28 & 0 & 28 & $\mathbf{5 6}$ & $\mathbf{1 6 8}$ \\
Tlalocohyla loquax & 91 & 66 & 0 & 0 & $\mathbf{1 5 7}$ & 104 & 0 & 2 & $\mathbf{1 0 6}$ & $\mathbf{2 6 3}$ \\
Hypsiboas rufitelus & 0 & 7 & 2 & 1 & $\mathbf{1 0}$ & 0 & 1 & 0 & $\mathbf{1}$ & $\mathbf{1 1}$ \\
Smilisca baudinii & 24 & 45 & 0 & 0 & $\mathbf{6 9}$ & 66 & 0 & 0 & $\mathbf{6 6}$ & $\mathbf{1 3 5}$ \\
Smilisca sordida & 3 & 0 & 0 & 0 & $\mathbf{3}$ & 0 & 0 & 0 & $\mathbf{0}$ & $\mathbf{3}$ \\
Smilisca puma & 2 & 9 & 0 & 1 & $\mathbf{1 2}$ & 9 & 0 & 0 & $\mathbf{9}$ & $\mathbf{2 1}$ \\
Smilisca phaeota & 0 & 1 & 0 & 0 & $\mathbf{1}$ & 1 & 0 & 0 & $\mathbf{1}$ & $\mathbf{2}$ \\
Unidentified hylid & 0 & 0 & 0 & 4 & $\mathbf{4}$ & 0 & 0 & 5 & $\mathbf{5}$ & $\mathbf{9}$ \\
\hline Total Individuals & 2971 & 732 & 230 & 133 & $\mathbf{4 0 6 6}$ & 3401 & 191 & 443 & $\mathbf{4 0 3 5}$ & $\mathbf{8 1 0 1}$ \\
Total Species & 10 & 11 & 6 & 8 & $\mathbf{1 2}$ & 10 & 6 & 7 & $\mathbf{1 1}$ & $\mathbf{1 2}$ \\
\hline
\end{tabular}


Table 4. Contributions of the top three contributing species to the total average dissimilarity in hylid species composition between the Cantarana and Research swamps in 2011. Species names: SELAE = Scinax elaeochrous; DEBRA = Dendropsophus ebraccatus; ACALL = Agalychnis callidryas.

\begin{tabular}{|c|c|c|c|c|c|c|}
\hline \multirow[b]{2}{*}{ Species } & \multicolumn{2}{|c|}{ Average Abundance } & \multirow{2}{*}{$\begin{array}{c}\text { Average } \\
\text { Dissimilarity }\end{array}$} & \multirow{2}{*}{$\begin{array}{l}\text { Diss./ } \\
\text { SD }\end{array}$} & \multirow{2}{*}{$\begin{array}{c}\text { Contribution } \\
\% \\
\end{array}$} & \multirow{2}{*}{$\begin{array}{c}\text { Cumulative } \\
\text { Contribution } \%\end{array}$} \\
\hline & Cantarana & Research & & & & \\
\hline SELAE & 8.78 & 2.07 & $31.30 \pm 1.14$ & 1.14 & 38.96 & 38.96 \\
\hline DEBRA & 2.47 & 0.04 & $18.96 \pm 1.18$ & 1.18 & 23.60 & 62.57 \\
\hline ACALL & 0.72 & 1.36 & $13.68 \pm 0.92$ & 0.92 & 17.04 & 79.60 \\
\hline
\end{tabular}


Table 5. Contributions of the top three contributing species to the total average dissimilarity in hylid frog species composition at the Research Swamp during different study periods. The value of the total average dissimilarity between years is shown in parentheses. Species names: ACALL = Agalychnis callidryas, AGALY SPP. = Agalychnis spp., DEBRA = Dendropsophus ebraccatus, SELAE = Scinax elaeochrous .

1982 and $1994(79.7 \%)$

\begin{tabular}{|c|c|c|c|c|c|c|}
\hline \multirow[b]{2}{*}{ Species } & \multicolumn{2}{|c|}{$\begin{array}{c}\text { Average } \\
\text { Abundance } \\
\end{array}$} & \multirow{2}{*}{$\begin{array}{c}\text { Average } \\
\text { Dissimilarity }\end{array}$} & \multirow{2}{*}{$\begin{array}{c}\text { Diss./ } \\
\text { SD }\end{array}$} & \multirow{2}{*}{$\begin{array}{c}\text { Contribution } \\
\% \\
\end{array}$} & \multirow{2}{*}{$\begin{array}{c}\text { Cumulative } \\
\text { Contribution } \\
\% \\
\end{array}$} \\
\hline & 1982 & 1994 & & & & \\
\hline SELAE & 7.53 & 0.11 & 23.49 & 0.97 & 29.49 & 29.49 \\
\hline AGALY SPP. & 3.94 & 0.61 & 17.41 & 0.90 & 21.85 & 51.34 \\
\hline DEBRA & 3.97 & 0.68 & 15.35 & 1.03 & 19.28 & 70.62 \\
\hline \multicolumn{7}{|c|}{2005 and $2011(76.4 \%)$} \\
\hline \multirow[b]{2}{*}{ Species } & \multicolumn{2}{|c|}{$\begin{array}{c}\text { Average } \\
\text { Abundance } \\
\end{array}$} & \multirow{2}{*}{$\begin{array}{c}\text { Average } \\
\text { Dissimilarity }\end{array}$} & \multirow{2}{*}{$\begin{array}{l}\text { Diss./ } \\
\text { SD }\end{array}$} & \multirow{2}{*}{$\begin{array}{c}\text { Contribution } \\
\% \\
\end{array}$} & \multirow{2}{*}{$\begin{array}{c}\text { Cumulative } \\
\text { Contribution } \\
\% \\
\end{array}$} \\
\hline & 2005 & 2011 & & & & \\
\hline ACALL & 3.39 & 1.36 & 28.68 & 1.25 & 37.55 & 37.55 \\
\hline SELAE & 0.00 & 2.07 & 17.86 & 0.80 & 23.38 & 60.93 \\
\hline DEBRA & 3.29 & 0.04 & 15.30 & 0.72 & 20.03 & 80.96 \\
\hline
\end{tabular}


Table 6. Analysis of Similarity (ANOSIM) pairwise tests of hylid frog species composition at the Cantarana and Research swamps in 2005 and 2011.

\begin{tabular}{lccc}
\hline Group & Global $\boldsymbol{R}$ & Significance & $\begin{array}{c}\text { Average } \\
\text { Dissimilarity\% }\end{array}$ \\
\hline 2005 Research, 2011 Cantarana & 0.372 & 0.001 & 81.9 \\
2005 Cantarana, 2011 Cantarana & 0.344 & 0.001 & 81.7 \\
2011 Cantarana, 2011 Research & 0.280 & 0.001 & 80.3 \\
2005 Research, 2011 Research & 0.238 & 0.001 & 76.4 \\
2005 Cantarana, 2011 Research & 0.185 & 0.001 & 74.9 \\
2005 Cantarana, 2005 Research & 0.024 & 0.139 & n/a \\
\hline
\end{tabular}


Table 7. Substrates used by hylids at the Cantarana Swamp. Values in columns 4-6 are percentages of all observations (column 3). Species abbreviations: ACALL = Agalychnis callidryas, ASALT = Agalychnis saltator, DEBRA = Dendropsophus ebraccatus, DPHLEB = Dendropsophus phlebodes, SBAUD = Smilisca baudinii, SBOUL = Scinax boulengeri, SELAE = Scinax elaeochrous, TLOQU = Tlalocohyla loquax.

\begin{tabular}{|c|c|c|c|c|c|}
\hline \multirow[b]{2}{*}{ Taxon } & \multirow{2}{*}{$\begin{array}{l}\text { Number of } \\
\text { substrate } \\
\text { categories }^{\text {a }} \\
\text { used }\end{array}$} & \multirow{2}{*}{$\begin{array}{c}\text { Number of } \\
\text { frogs } \\
\text { observed } \\
\end{array}$} & \multicolumn{3}{|c|}{ Substrate } \\
\hline & & & Aroid & Graminoid & Other \\
\hline ACALL & 8 & 93 & 31 & 28 & 41 \\
\hline ASALT & 7 & 137 & 52 & 14 & 34 \\
\hline DEBRA & 8 & 1576 & 42 & 46 & 12 \\
\hline DPHLE & 4 & 37 & 19 & 73 & 8 \\
\hline SBAUD & 5 & 51 & 2 & 4 & 94 \\
\hline SBOUL & 4 & 36 & 5 & 67 & 28 \\
\hline SELAE & 8 & 694 & 19 & 67 & 14 \\
\hline TLOQU & 7 & 105 & 74 & 13 & 13 \\
\hline
\end{tabular}

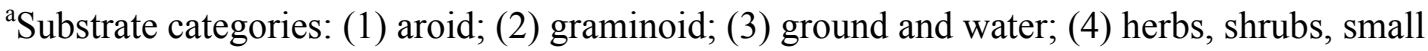
trees, unidentified plants; (5) ferns, vines, palms, epiphytes; (6) trees; (7) dead plant debris; (8) artificial structures (boardwalk, rope, pvc pipe). 
Table 8. Substrates used by hylids at the Research Swamp. Values in columns 4-6 are percentages of all observations (column 3). Species abbreviations: ACALL = Agalychnis callidryas, ASALT = Agalychnis saltator, DEBRA = Dendropsophus ebraccatus, DPHLEB = Dendropsophus phlebodes, SBAUD = Smilisca baudinii, SBOUL = Scinax boulengeri, SELAE = Scinax elaeochrous, TLOQU = Tlalocohyla loquax.

\begin{tabular}{|c|c|c|c|c|c|}
\hline \multirow[b]{2}{*}{ Taxon } & \multirow{2}{*}{$\begin{array}{l}\text { Number of } \\
\text { substrate } \\
\text { categories }^{\mathrm{a}} \\
\text { used }\end{array}$} & \multirow{2}{*}{$\begin{array}{l}\text { Number of } \\
\text { frogs } \\
\text { observed }\end{array}$} & \multicolumn{3}{|c|}{ Substrate } \\
\hline & & & Aroid & Graminoid & Other \\
\hline ACALL & 8 & 329 & 21 & 48 & 31 \\
\hline ASALT & 8 & 115 & 23 & 34 & 43 \\
\hline DEBRA & 7 & 815 & 32 & 60 & 8 \\
\hline DPHLE & 6 & 145 & 9 & 85 & 6 \\
\hline SBAUD & 7 & 58 & 9 & 5 & 86 \\
\hline SBOUL & 7 & 101 & 6 & 79 & 15 \\
\hline SELAE & 8 & 2241 & 5 & 89 & 6 \\
\hline TLOQU & 4 & 156 & 4 & 94 & 2 \\
\hline
\end{tabular}

aSubstrate categories: (1) aroid; (2) graminoid; (3) ground and water; (4) herbs, shrubs, small trees, unidentified plants; (5) ferns, vines, palms, epiphytes; (6) trees; (7) dead plant debris; (8) artificial structures (boardwalk, rope, pvc pipe). 


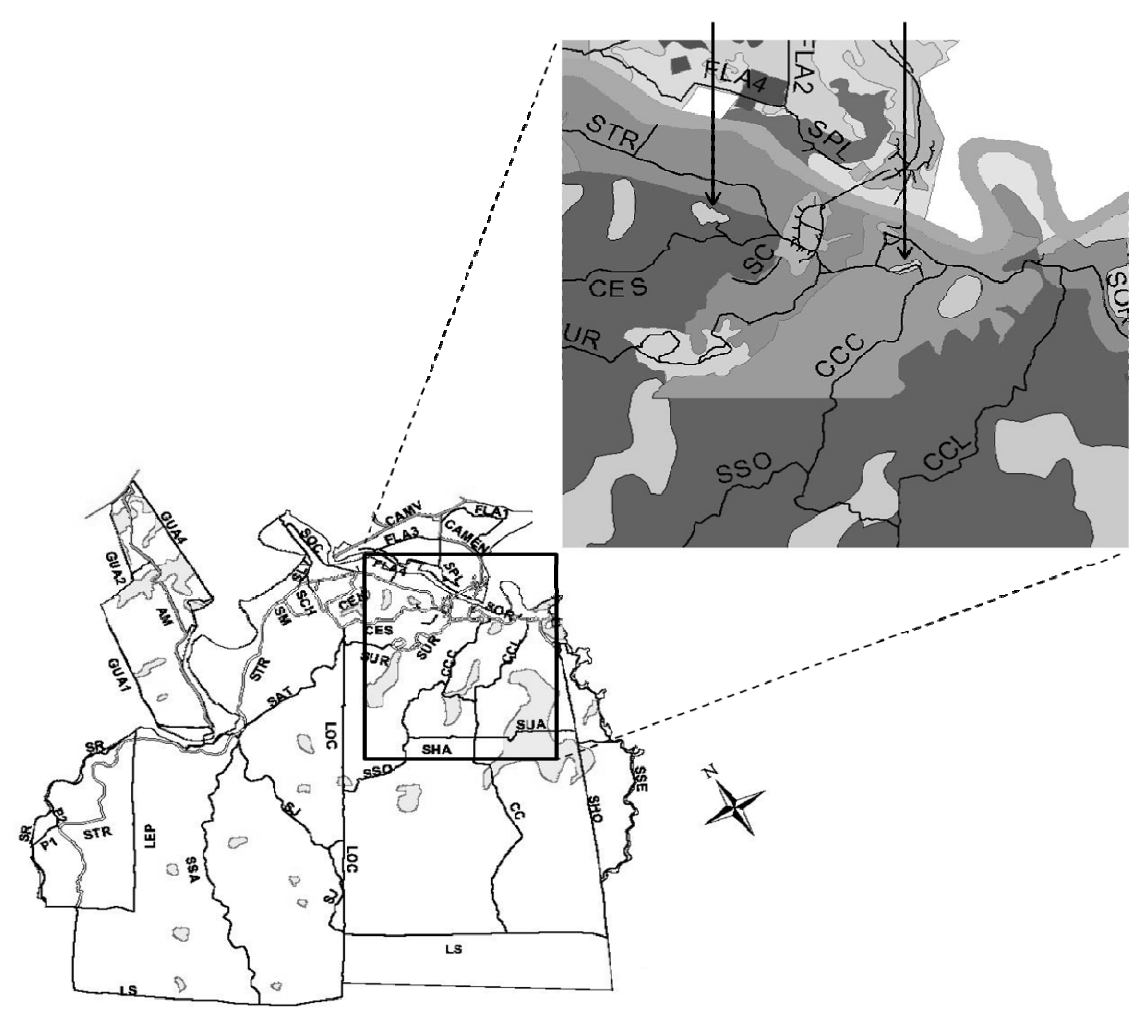

Figure 1. Swamps and trail systems at La Selva Biological Station. 

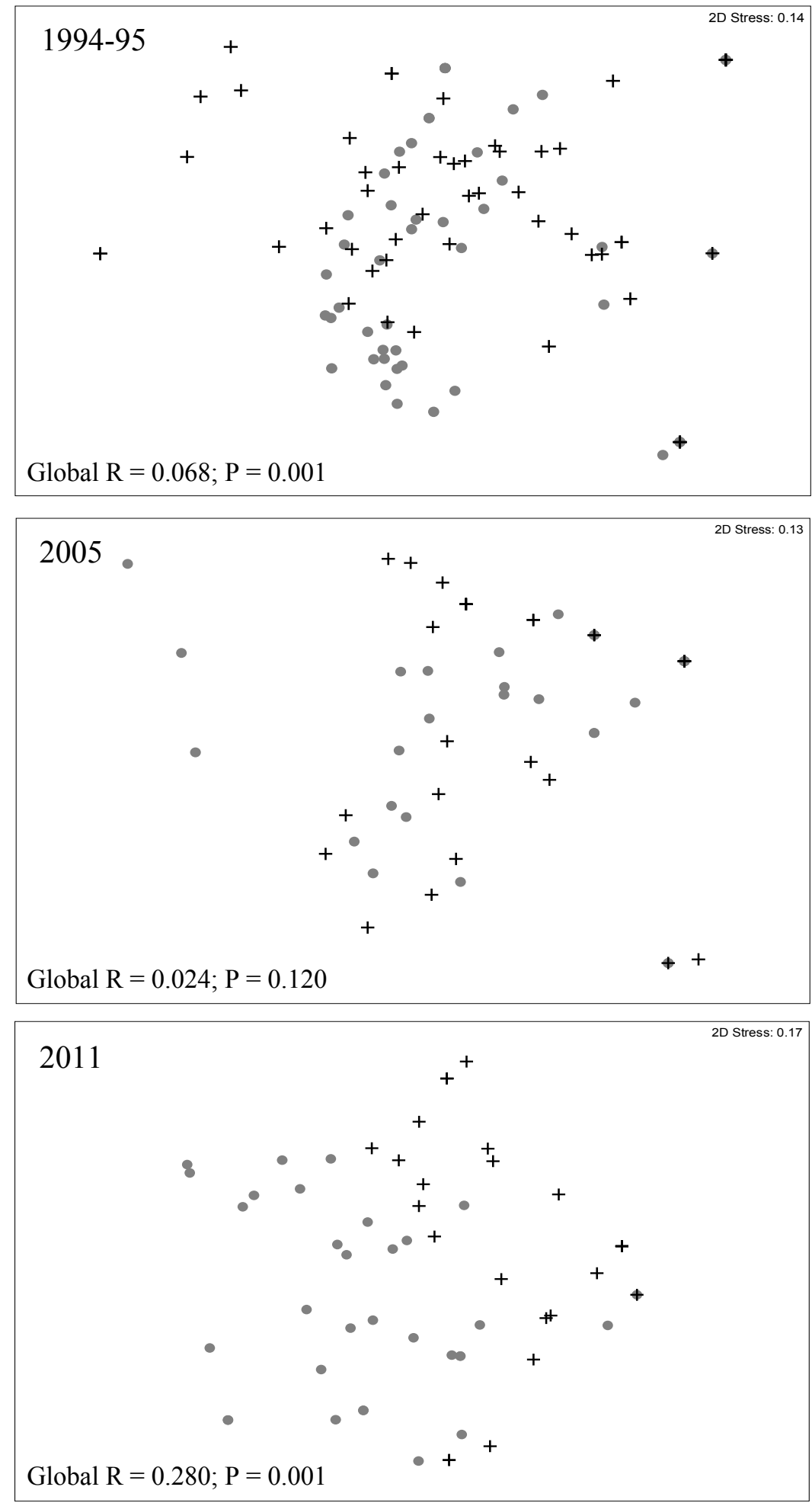

Figure 2. Non-metric multidimensional scaling (nMDS) plots of pooled species relative abundance. Circles represent the Cantarana Swamp. Crosses represent the Research Swamp. 

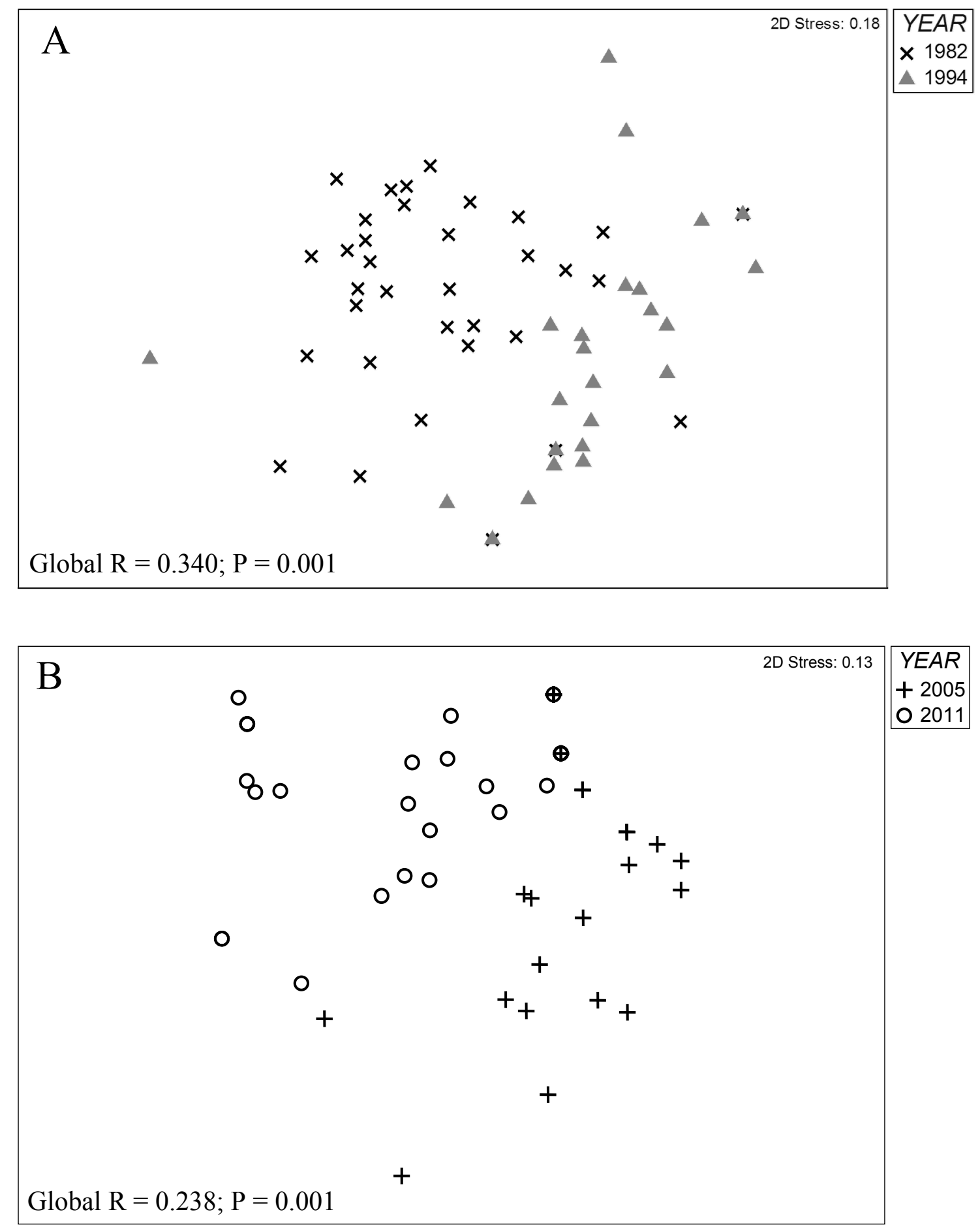

Figure 3. Non-metric multidimensional scaling (nMDS) plots of pooled species relative abundance for hylid frogs at the Research Swamp (A) in 1982 and 1994 and (B) in 2005 and 2011. 


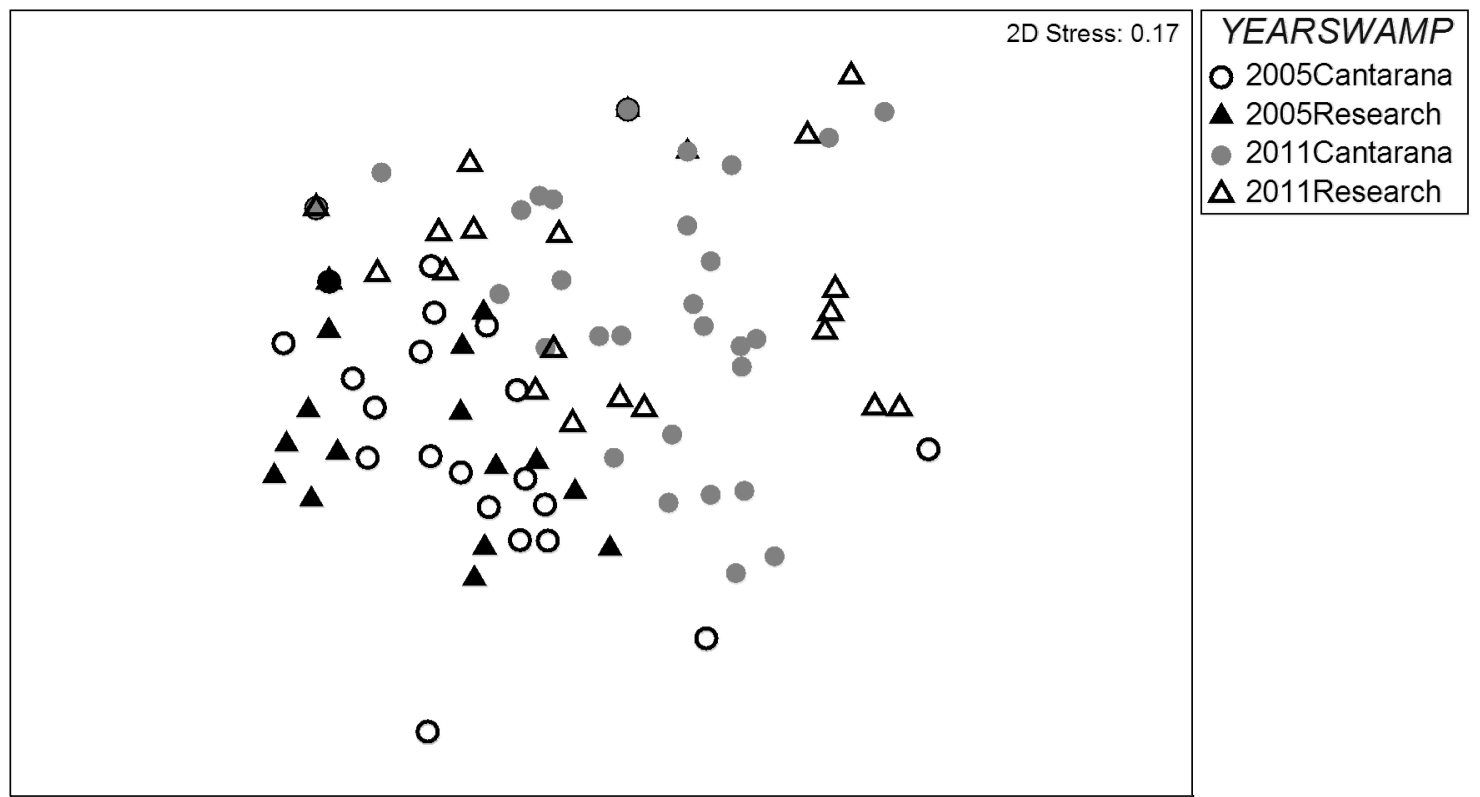

Figure 4. Non- metric multidimensional scaling (nMDS) plot of pooled species abundance for hylid frogs at the Cantarana and Research swamps in 2005 and 2011. 


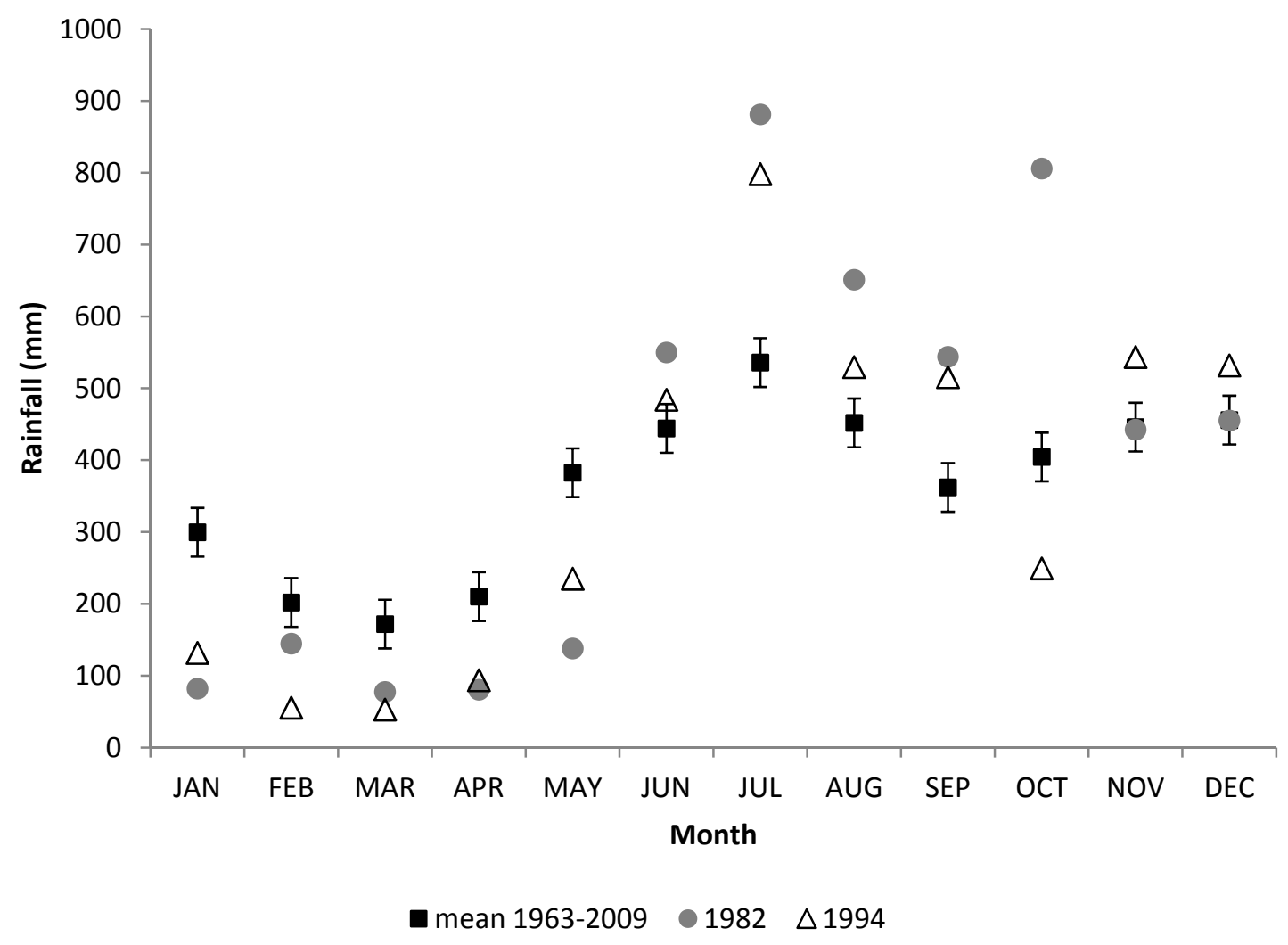

Figure 5. Mean monthly rainfall $(\mathrm{mm}) \pm 1$ SEM at La Selva over 47 years (1963-2009; black squares) and monthly totals for 1982 (gray circles) and 1994 (open triangles). 


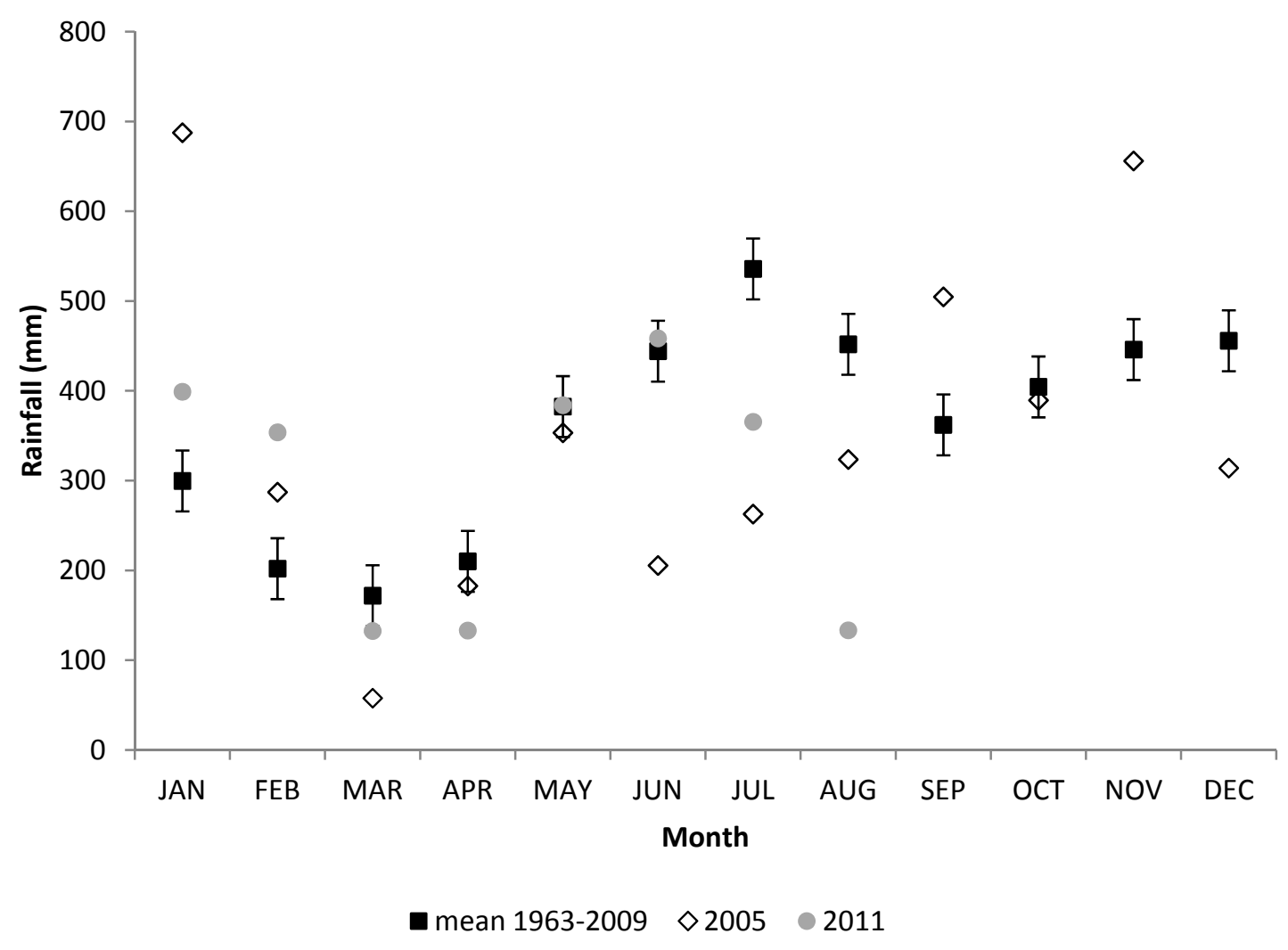

Figure 6. Mean monthly rainfall $(\mathrm{mm}) \pm 1$ SEM at La Selva over 47 years (1963-2009; black squares) and monthly totals for 2005 (open diamonds) and for 2011 (gray circles). In 2011 only data for January - August are shown. 

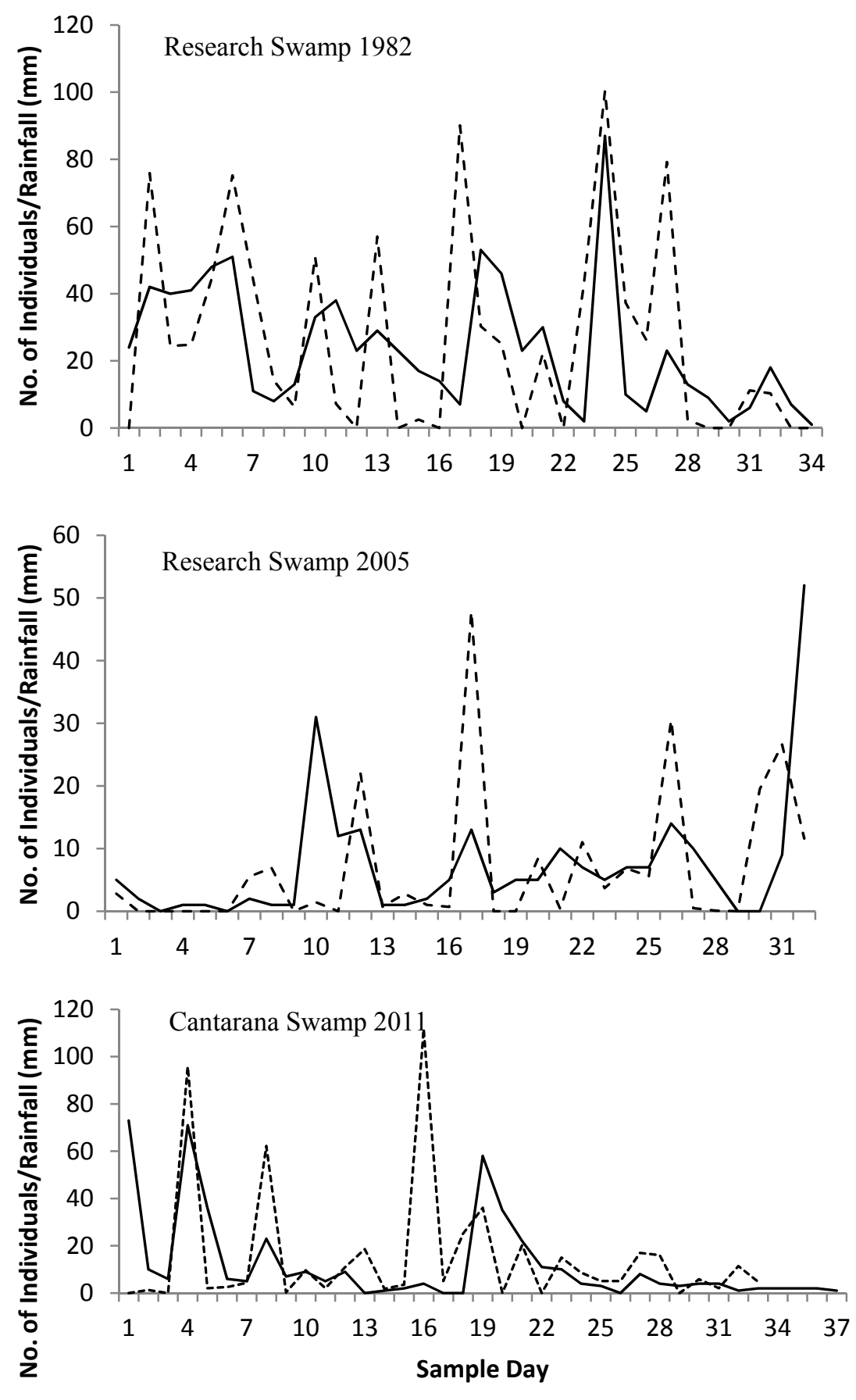

- Total no. of hylid frogs ------ Rain $(\mathrm{mm})$

Figure 7. Change in the total number of hylid frog individuals (solid line) with rainfall $(\mathrm{mm})$ (dotted line). 